\title{
SOCIETIES RESILIENCE FOR CONFRONTINC COVID-19 BASED ON GOTONG ROYONG TRADITION (MUTUAL COOPERATION)
}

Bahagia, Rahmadanti, Indriya

Universitas Ibn Khaldun Bogor

Email corresponding: bahagiagia59@yahoo.co.id

\begin{tabular}{|c|c|c|}
\hline Submitted: & Accepted: & Published: \\
$10-10-2020$ & $28-11-2020$ & $31-01-2021$ \\
\hline
\end{tabular}

\begin{abstract}
The research investigates about societies resilience for facing COVID 19 based on cooperation. The method used is ethnography qualitative approach. The method is selected because of research linked to tradition and cultural, societies, and community. Data are collected by in-depth interview, observation, and documentation. Purposive sampling technique is implied to determine respondents. The outcome is analyzed with triangulation data. The result is cooperation tradition have been implemented in some activity including mutual helping and cooperation in public activity and mutual helping when there are societies suffer from the ailment. It can create societies resilience because there is social power to bolster individual resilience by way of mutual helping and visiting when the member of societies impacted from the disease. Besides, cooperation has invented food resilience because societies collectively bringing food to people who they are combated by a disease like COVID 19. At the same time, people who suffer from a disease like COVID 19 can achieve physiology resilience. A person who they have been encouraged by the societies collectively easier to recover from the ailment because the person does not experience stress for confronting disturbance of life. As result, the person has happiness and produce happy hormones rather than sadness hormone. Another finding is societies have moved from traditional social relation to online relation without face to face. The impact is societies react resilience because they avoid from COVID 19 attack through reducing face-face meeting frequency. Even societies literate about update information related to COVID and literate about online and social media. It boosts resilience societies because a person has information about COVID 19.
\end{abstract}

Keywords: Societies resilience, cooperation, culture, tradition

\section{Introduction}

The World Health Organization (WHO) has made the corona COVID-19 virus as world disease epidemic and have an impact on local and national food availability. The food system is disrupted starting from the upstream (production) and downstream (marketing) levels. The impact of the food supply is worrying human hunger has doubled, except for countries that can overcome the problem of COVID 19 (ECFood, 2018 in Galanakis, 2020). The COVID 19 outbreak also have an impact on decreasing food stock and demand, production, and distribution capabilities, thus indirectly reducing purchasing power, and causing poverty and vulnerability in society (FAO, 2020). According to Naja \& Hamadeh (2020) Covid-19 causes problems such as limited access to food due to disrupted transportation and food delivery. There is even a hoarding of necessities which results in market disruptions. At the same time, it has an impact on nutritional quality due to reduced expenditure, including buying food (Scarmozzino \& Visioli, 2020).

Food hoarding accompanied by excessive consumers to buy food has an impact on food scarcity and food vulnerability (Power et al 2020). Coupled with the impact of social distancing to tackle the COVID-19 outbreak, many restaurants, hotels, and shops have to close even though the store is a food center for the community (Goetz \& Schmidt 2020). Even COVID 19 has an impact on various sectors including the transportation sector. People are worried about travelling using public transportation because their health is not guaranteed. Therefore, they prefer to use private transportation (Pawar et al 2020). The 
existence of Covid-19 has a significant impact on public psychology such as anxiety, worry, sadness and excessive fear (Poudel \& Subedi 2020). In China, Covid-19 also has an impact on mental health such as mild stress, feelings of horror and worry and its impact on the quality of life of local people (Yingfei \& Zheng 2020).

In Indonesia, Covid-19 harms the Indonesian economy, especially in the household sector due to the absence of economic activity (Susilawati et al 2020). Another impact of the pandemic on the Indonesian maritime industry occurred in 3 main sectors, namely the national shipping sector, the shipbuilding sector, and the port sector (Arifin 2020). COVID 19 makes people vulnerable to various problems, an approach is needed to create a community resilience for facing Covid-19. Cultural and traditional approaches can be a solution to make people resilient for confronting COVID 19, namely by exploring the traditional values of cooperation in the community.

Tradition is a description of human attitudes and behavior that have been passed down from generation to generation for a long time, which does not mean that they must be accepted, valued, assimilated, or stored (Daud et al. 2018). Roriq (2019) said that tradition can be interpreted as anything that was inherited by previous people in the form of symbols, principles, materials, objects, or policies. The inherited traditions can change or survive as long as they are appropriate and relevant to periods.

Meanwhile, cooperation can be interpreted as doing something together as a form individual participation that can render positive values (Yuliyanti, 2019). Wati \& Hidayah (2017) reported that cooperation is a form of work carried out together to achieve the desired result. Cooperation activities belong to the original tradition of the Indonesian state which means cooperation between communities (Simarmata et al 2020). Cooperation activities are carried out voluntarily without any coercion (Bintari \& Darmawan, 2016).

Suri (2017) reveals mutual cooperation can be classified as cultural heritage passed down from generation to generation to form a social value system. There are many examples of mutual cooperation activities in Indonesia including coconut sugar craftsmen in Ketanda Village by forming the Argo Mulyo Jati organization which aims to improve the position of the craftsmen in unbalanced social relations (Faedlulloh 2017). Crowdfunding can also be said as a form of new cooperation. Crowdfunding has a connection to a fundraising model through online sites with several people who play an important role such as project owners, crowdfunding organizations, and donors. For example, the Kitabisa.com platform (Irfan 2016).

In Muna District, mutual cooperation activities in agricultural activities ranging from land clearing activities, fencing activities, planting activities, harvesting activities, and transporting harvest products. In the sociocultural aspect, mutual cooperation is carried out such as the implementation of a wedding party, house construction, circumcision, seclusion, the celebration of Islamic holidays and death ceremonies (Sinaini \& Iwe 2019). In Malaysia, mutual cooperation namely Malaysian art of the Cekak Strait is conducted through the slaughter of sacrificial animals during Eid al-Adha (Ahmad, et al. 2018). Another example, youth who are members of the Youth Organization in Tempur Village, work together to clean the river from garbage and the proceeds are used to make crafts such as bags (Widjanarko 2019). Sukmana (2018) said that in Malang district, the community realizes mutual cooperation activities by protecting springs and making rules so that all obey to protect the water.

Other mutual cooperation activities such as celebrating death, mutual cooperation to process rice fields, build houses and cooperatives (Umar 2017). In the marriage ceremony, the Kelara community promotes the A'dengka Pada. In this activity, families and relatives work together to prepare mortars, prepare tools and materials which are used in these ceremonies (Quraisy \& Asnaeni 2017). The form of mutual cooperation is carried out in the Rereongan Serumpi tradition. The people of Situ Udik village have taken this action by raising funds from the community to help other people, especially in ransacking an unsuitable house. Each person contributes 100 rupiahs without reciprocation (Mujahidin et al. 2020). Mutual cooperation applies several principles including each activity that is always carried out jointly, not individually. As well as promoting a willingness to help others. Social values ranging from mutual trust, care and collective work become the substance. This activity has the impact of building a community that is resilient to life's challenges in the form of disasters, disease outbreaks and food problems. Community resilience is built through mutual cooperation activities because mutual 
cooperation does not only increase individual abilities but rather increases group capacity.

While community resilience can be interpreted into several meanings including the ability to withstand stresses and shocks and the ability to care for students to run well (Rockefeller Foundation and ISET in Fitra, 2018). Bahagia et al (2020) reveal that resilience is the capacity of social for facing the stressor. Istanabi et al. (2018) resilience can be mentioned as the integration among adaptation, mitigation and inovation. Meanwhile, according to Utami \& Helmi (2017) resilience or toughness is the human ability to face or overcome difficulties in life. Resilience can be interpreted as the ability to overcome stressors or try to develop during challenges and difficulties in life (Mawarpury \& Mirza 2017). It is a process of adapting, finding solutions to solve a problem in the community (Arrahma et al. 2017). In addition, individual resilience is a person's ability to rise and develop into a better human being from all the difficulties he faces and go through certain phases until he is comfortable with his current condition (Maslahah \& Khoirunnisa 2020). Preparedness efforts are a form of community resilience to a disaster. For example, floods (Pattipeilohy et al. 2019).

Cooperation is also a form of social resilience by way of the awareness and interaction of the community towards neighbors and the surrounding environment during floods (Ciptaningrum \& Pamungkas 2017). In traditional communities such as the Urug customary community, people store foodstuffs to deal with disasters instead of trading crops (Bahagia et al. 2020). Cooperation will also have an impact on the food system resilience. People are resilient to face food problems when times are difficult, so they avoid hunger. The activity of helping each other to help the community becomes a social force to produce food for those affected by the disease. This research will try to analyze the resilience of society in facing COVID 19 based on the cooperation tradition. There are several objectives of this research, including how the values of cooperation can sustain food so that people who are sick can be resilient in facing life's challenges. Another objective is to explore the values of cooperation on social resilience. The next objective is to analyze the values of cooperation related for supporting psychology resilience because the societies who suffer from ailment can impact to react the rate of stress of people. Lastly, find out about the connection online or digital literacy documents to support resilience to face COVID 19. The societies who they have update information about COVID 19 have affected to resilience because the person comprehend how avoid COVID 19 through several action.

\section{Methods}

Research uses ethnography with a qualitative approach method. This research was conducted in Nanggewer Village, Cibinong District, Bogor Regency, West Java Indonesia. Ethnography is a set of methods that discuss notes and how to write about a community in a community (Achmad \& Ida 2018). Ethnography is an emphasis on cultural aspects. There is a close relationship between ethnography culture as a result of creativity (Kamarusdiana 2019). A study can be said to be ethnographic if field researchers pay attention to the context as well as conditions related to the actions and statements of the people being observed (Windiani \& Farida 2016). Seran \& Mardawani (2020) say ethnography discusses how humans live. Ethnography means discussing the culture of a society (Ramadania \& Jamilah 2019). Ethnography is categorized as qualitative research because the research involves the participation of researcher to interview and observation as well as documentation the location and the object of research. Rutberg \& Bouikidis (2018) explain that qualitative research is described in a descriptive narrative. The purpose of qualitative research is to understand the phenomenon of experience without the need to detail the relationship between the variables involved (Zaluchu 2020). While the sampling technique was done employing the purposive technique. This method is used to select respondents who are considered able to explain related to the research.

The head of the neighborhood unit is the main source of respondents because qualitative research aims to obtain quality data. The head of the neighborhood, abah Suparta and his wife, Dia. The data that have obtained include data related to the types of cooperation activities in the community. Other data that will be obtained are data related to cooperation as social resilience because the activities are carried out together and work for hand in hand. It is always done in groups at a collective social level.

Also, data related to cooperation and psychological resilience will be sought because of cooperation to reduce the level of people 
stress who they are suffered from disease like COVID 19 as well as another ailment. Even it increases the spirit life of individual when the collective action encourages the person. The other data is the data related to food resilience online factors as support for realizing a resilient community against COVID 19. Data collection will be carried out by way of In-depth interview with respondent. The data from Indepth interview will be complemented with observation data, literature, and documentation. These data will be analyzed qualitatively to obtain the expected data. To do this, the data that has been obtained will be analyzed using a triangulation approach. Triangulation, by combining theories, methods, or observers in a research study, can help ensure that fundamental biases arising from the use of a single method or a single observer are overcome. It can be supported that combining multiple observers, theories, methods, and empirical materials, researchers can hope to overcome the weakness or intrinsic biases and the problems that come from single method, single-observer, single-theory studies (Yeasmin \& Rahman 2012). This method analyzes the data that has been obtained by combining data from observations, documentation, and interviews. In this research, the result is derived from several method including the combination in-depth interview, observation, and documentation method. The mixing of this method analyze can produce valid data because the result based on integration three of method.

\section{Result and Discussion}

Mutual cooperation has been tradition and cultural in the village of Nggelewer. There is some activity that can be categorized as mutual cooperation including people shoulder in shoulder to construct the house of the people when the individual house experience damaged. The form of this activity also releases in cleaning of village environment from some sewage and garbage. The other form is the people together to help person who they face to serious sick because there is another person responsible for it. Abah Suparta as head of the neighborhood reveals that cooperation have some meaning such as helping each other, working hand in hand, working together but not being individualistic, and sincere. Mutual cooperation comprises mutual helping, if someone has been aided, the person does not need to reply because it is based on the willingness of the person who helps. Helping each other does not indicate like a debt that must be repaid. cooperation prioritizes collective work so that everyone joins the group. Abah Suparta said that If the member of societies does not attend to mutual cooperation activity, the individual does not receive punishment because it is based on willingness of person whether they intent to come or no. However, he mechanism of cooperation is up to that person. For example, If the parents work and do not have time to come, the parents can send their adult children. If you do not have adult children, person can replace himself by providing food to those who participate in mutual cooperation. It has been boosted by another finding when someone does not attend mutual cooperation, that person can ask someone else to come by paying someone they trust or contributing to give money (Bahagia et al 2020).

In combating disease like COVID 19 can be used because social power needs to assist another person who have experienced ill. For instance, the societies have good habit like asking some money to each person for aiding to impacted person. The power of community who they render the money have assisted the infected people. The impact is the people can increase the capacity for facing COVID 19 and some diseases because there is bolstering based mutual helping. In another real action, when someone is sick, everyone visits because they have an attitude of social belonging which then makes them aware that they must come to visit someone who is sick. In the village of Nggelewer, this mechanism started when a group of people came together to visit the sick person. Their principle is that everyone who is sick like those affected by COVID 19 is not a disgrace and does not need to be isolated. Likewise, with someone who is attacked by other types of diseases. There are several mechanisms in this, ranging from people hanging out and bringing food and drink to the sick. People who are sick become resilient in facing COVID 19 because basic needs are provided by residents. The second pattern where the societies visit sick people at their home without giving food and drink. It must be encouraged by the preparedness typical funding for people who experience sick such as the residents provide a fund to assist the people who they need medical treatment. However, the fund is not fully supported overall of medical. When someone dies, the community will help pay for the burial of the corpse, bathe, and the purchase of cloth. These funds only complementary fund because funds for sick people have also been bolstered by the 
government through the BPJS. Meanwhile, the form of cooperation tradition produces social bridging and social bonding. The head of the neighborhood unit as a key figure in the community becomes the information link if there are developments about the COVID 19 disaster. The head of the neighborhood unit gets information from the media and the health office. Once the information is obtained, the information is distributed to the residents through social media. These findings are valuable for resilience to deal with COVID 19. First, there is an adaptation for someone in a vulnerable condition such as one who is experiencing illness. The tradition of mutual cooperation has made a person resilient to face the pressures of life or challenges such as illness because basic necessities such as rice, eggs, vegetables, vitamins have been met by residents.

If people live individually, support such as life motivation will below. Mutual cooperation that is collective action means collective support comes to support people who are sick. In the end, social resilience was achieved where the community came together to face disasters including the COVID 19 problem and other types of disasters. Of course, the individual strength is weaker to achieve a higher degree of toughness than the collective. The community guarantees the need for food and drink for the sick so that the sick can avoid hunger. Mutual cooperation directly suspends people from the foods resilience system.

The principle of mutual cooperation is like working hand in hand, helping each other, and working together in groups as a power to produce food. After that, societies have conducted collectively for distributing the food when there are people who they are attacked by COVID 19 and other sorts of diseases. Food resilience is identical to the resilience of a person or society to face difficulties and times of food shortages. People must ensure to fulfill fundamental necessities for confronting climate, disaster, and disease because people can experience suffer from ailment (Bahagia, B. et al 2020). Communities affected by COVID 19 attaint resilient in facing COVID 19 when collective action as method for assisting impacted people. All members of the community voluntarily bring food and drink to the house of someone who is sick. The recipient will be free from hunger and increase the body's immunity of the food recipient because vitamins and minerals are filled in groups. It is avoiding someone from a shortage of food during illness, he only focuses on healing without thinking about basic needs. After that, mutual cooperation increases psychological resilience or individual resilience to deal with stressful situations due to diseases such as COVID 19.

A person experiencing stress due to a disease such as COVID 19 makes a person stressed due to fear of death, the burden of living children, and various pressures including isolation from neighbors so that social collective relations are cut off. Even though the physical and social disconnection in life is the heaviest burden as a human being. This condition makes a person stressful. Stress can be said as a burden of life, anxiety and fearlessness between expectations and reality are not the same (Nurlaila 2016). This method allows people who are sick to recover quickly because they are motivated to be enthusiastic about living and recovering together. Sisto et al. (2020) explain the psychology of resilience as the ability to maintain a persistent level that is oriented towards achieving existential. Mirza (2017) states that psychological resilience is if the family can cope with non-physical problems, positive emotional control, positive self-concept (including hope and satisfaction) and husband's concern for his wife. Close relationships and family are necessary for resilience to manifest (Prime, Wade \& Browne 2020).

Petzold et al. (2020) said that there are several strategies to increase psychological resilience, including maintaining a healthy lifestyle, having social relationships or social contact, accepting anxiety and negative emotions and efficacy. Visiting each other and helping each other in mutual cooperation activities can achieve psychological resilience. Neighbors and siblings will support psychologically through speech so that the sick does not feel lonely. Meanwhile, a person's immunity also increases because of social support. When someone is sad then their immune will go down and when someone is happy or happy the level of immune will go up. People who are sick when visited by neighbors will be happy so that they relieve stress from the disease they are facing. It is even more stressful if there is a social exclusion in COVID 19 patients when doing independent isolation.

Whereas stressed people will release the hypothalamic-pituitary-adrenal (HPA) axis stress hormone-releasing corticotropin-releasing hormone $(\mathrm{CRH})$ and followed by the release of 
adrenocorticotropin hormone (ACTH) from the pituitary gland so that a person will be stressed (Larasati 2016). Especially for mothers, it is easier to stress because there are two burdens, namely the workload on the household and office (Handayani \& Ratnasari 2019). Utami (2017) reports that the stress response has a psychological impact on causing emotional distress and behavioral changes. There are several stress levels including (1) Alarm Reaction which resembles a fight or flight response (2) Resistant Phase, which is when the body tries to compensate for existing stressors and (3) Exhaustion Phase, which is when the body is no longer able to compensate for the stressor due to exhaustion. Selye 2015 in Nathania, Dinata, \& Griadhi 2019). If this condition cannot be overcome, it will reduce endurance or decrease immunity (Widyastuti et al. 2020). A sense of happiness arises when the social environment influences such as support from neighbors.

The cure for happiness comes and eliminates feelings of loneliness and anxiety even though the illness is very severe. Values in cooperation activities such as visiting each other will strengthen the immunity of someone who is sick because they are still socially connected. When the COVID 19 outbreak visited, you did not have to immediately meet and enter the house of a sick person. The community maintains a distance according to the health protocol, namely 1.5 to 2 meters. So, there is no barrier to meeting sick people even though he is exposed to COVID 19. As a result, a positive response will occur to face difficult situations (Vella \& Pai 2019). The impact of collective support makes a person feel happy or happy, stress will disappear and produce endorphin hormones. Endorphin hormones are usually produced in brain neurons to deal with stress, anxiety, and depression (Ferreira et al. 2018). Triswanti (2015) endorphins make a person feel happy and happy, this hormone acts like morphine and is even said to be $\mathbf{2 0 0}$ times greater than morphine.

In addition, the community's resilience to resolve and adapt to life's calamities is supported by social bridging and social binding. Social bridging, a key figure in Ngadewer village, is the center of information for the community related to the development of COVID 19, information on how to overcome and preventive measures as well as information on health protocols that must be done. There are health workers such as Pak RT as a liaison for citizens to the government so that the community does not miss information, especially about the development of COVID 19. In the end, residents did not miss the latest updates about the COVID 19 outbreak. As a result, the community was resilient to COVID 19 because they were not blind to information about COVID 19. At the same time increasing the digital literacy of the community during the COVID 19 pandemic (Sitohang, Rahadian \& Prasetyoputra 2020).

Hanik (2020) explains that media literacy is related to knowledge and skills to use digital media, communication tools, or networks in finding, evaluating, using, making information, and utilizing it in a healthy, wise, intelligent, thorough, precise, and law-abiding manner. to foster communication and interaction in everyday life. People during a pandemic must adapt to using online media and digital media because the state of the outbreak makes people have to transform themselves from face-to-face use to digital media. As a result, face-to-face meetings are less frequent but more frequent in online media. People who previously did not understand the use of digital media must learn from their children, neighbors, or learn on their own (Self-learning). Critical environmental conditions have influenced people to change their behavior from conventional and traditional behavior to a society that is literate with online media.

At the same time, society has achieved resilience because society has chosen to carry out transformation as a form of society adjusting to the environment. The impact is that face-to-face meetings are increasingly rare, and it seems like a social relationship decision has taken place, even though it has moved towards the digitalization of friendship (social fabric). Even Sampurna, Kusumandyoko \& Islam (2020) said that the use of digital media increases public awareness because it can be posted on websites related to the number of patients who have recovered, the latest information on COVID 19, information about how many patients have recovered so that people are motivated to take precautions against the COVID 19 outbreak. The use of digitalization media can also reduce the spread of negative information during the COVID 19 pandemic (Sutrisna 2020). In the end, the community is resilient with COVID 19 information and resilient to deal with and the social ties are getting stronger during the pandemic.

Online and digital media have changed people's behavior into a society that maintains the mitigation of COVID 19 by reducing faceto-face meetings, meetings, and casual chatting. 
Then, residents have strong social bonding between them before COVID 19. This is evident from every sick citizen, so all must contribute without any orders from village and village leaders. Every citizen is not forced to allocate time and energy to visit and support the sick, but in fact, individual awareness grows which then merges into collective awareness. Also, every sick citizen will be given a change of funds and food, this reality proves that society has a social bond or link. When COVID 19 arrived, the social ties were also getting stronger because they did not meet but met on social media like WhatsApp.

\section{Conclusion}

Mutual cooperation has been released through some activity including mutual assisting, mutual working, mutual giving collectively instead of individual level. In implementing of cooperation, no enforcement for an individual who they do not attend to joint mutual cooperation activity, but the person has the highest awareness that an individual must be involved. When the person does not attend the activity, individual participate to purchase food and beverage for the person who they conduct mutual cooperation or sending a person as his change position. The other is mutual cooperation include community funding. The funding is owned by societies which can be used for assisting a member of societies for health cost. Besides, mutual cooperation is implied in societies when a member of societies experiences sick. There is some pattern including societies only visit the person without bringing food and beverage and the other allocate funding, food, and beverage to a person who they suffer from the ailment. It creates societies resilience because there is supporting socially and collectively to assist the person.

Immediately, food resilience achieves because a person who suffers from ailment obtain some food and beverage continuously until the individual heal from disease. The impact is a person have avoided from the scarcity of food and beverage as well as a shortage of nutrient. The other impact is the person who encourages collectively to recover from disease burden like COVID 19 can be easier to heal instead of personal lack of bolstering from the social environment. As result, a person has happiness and produce happy hormone rather than sad hormone. Directly, the rate of spirit for healing attaint through cooperation. The other is cooperation enchant social relation and social bridging. A person with another person like family because cooperation makes them closer to each other. Social bonding also is the value of cooperation because the head of the neighborhood unit as bridging for societies to obtain updated information from some sources like health officer and village office. Lastly, COVID 19 have encouraged the person to learn digitalization media because of COVID 19 impact on reducing traditional relation like face to face. Directly, societies achieve resilience because they reduce the intensity for meeting physically, but they strengthen social relation through the online system. The other advantage is societies have update information about COVID 19 faster than manual information. The societies who literate about COVID 19 more power than illiterate about COVID 19.

\section{References}

Achmad, Z. Abidin \& R. Ida. (2018). Etnografi Virtual Sebagai Teknik Pengumpulan Data Dan Metode Penelitian. The Journal of Society \& Media, 2(2), 130-145.

Ahmad, M. M. A., Jaih, A. M. M., \& Ismail, A. M. (2018). Gotong-royong and Halal Slaughter Practice in Feast Held by Seni Silat Cekak Malaysia. International Journal of Academic Research in Business and Social Sciences, 8(5), 1047-1056.

Arifin, M. D. (2020). Impacts of Coronavirus COVID-19 on the Global Shipping and Maritime Industry in Indonesia and How to Overcome the Coronavirus Outbreak Based on WHO and IMO recommendations.

Arrahma, F., H. Arrachim \& M. Irfan. (2017). Resiliensi Masyarakat Kampung Cadas Gantung Kabupaten Bandung. Jurnal Penelitian dan PKM, 4(2), 129-389.

Bahagia, B., F.M. Mangunjaya, Z. Anna \& R. Wibowo. (2020). Indigenious Knowledge of Urug Societies For Agriculture Irrigation In Bogor West Java. Jurnal Sosial Humaniora 11 (2):169-181.

Bahagia, B., F.M. Mangunjaya, R. Wibowo, Z. Rangkuti, M.A. Alwahid. (2020). Leuit and prohibition forest: Indigenous knowledge of an Urug community resilience. Harmoni Sosial: Jurnal Pendidikan IPS 7 (2):130140.

Bahagia., F.M. Mangunjaya, R. Wibowo, M.A. Alwahid. (2020). Resilience of Farming Labours Based on Bawon System Tradition and Ani-Ani Traditional Appliance In 
Indigenous Community of Urug Societies In Bogor, West Java. Kawistara 10 (2):251263.

Bintari, Pramudyasari Nur \& C.Darmawan. (2016). Peran Pemuda Sebagai Penerus Tradisi Sambatan Dalam Rangka Pembentukan Karakter Gotong Royong. JPIS: Jurnal Pendidikan IImu Sosial, 25(1), 57-76.

Ciptaningrum, M. Utami \& A. Pamungkas. (2017). Penilaian Resiliensi Dimensi Sosial Berdasarkan Konsep Climate and Disaster Resilience Initiative (CDRI). Jurnal Teknik ITS, 6(2), 539-543.

Daud, W., S. Arifin \& D. Dahlan. (2018). Analisis Tuturan Tradisi Upacara Ladung Bio' Suku Dayak Kenyah Lepo' Tau Di Desa Nawang Baru Kecamatan Kayan Hulu Kabupaten Malinau: Kajian Folklor. Jurnal Ilmu Budaya, 2(2):167-174.

Destindira, S. \& F. T. Nasdian. (2018). Hubungan Industrialisasi Pedesaan dengan Tingkat Resiliensi Rumah Tangga Petani. JSKPM: Jurnal Sains Komunikasi dan Pengembangan Masyarakat, 2(6):745-758.

Faedlulloh, Dodi. (2017). Modal Sosial Dan Praktik Gotong Royong Para Pengrajin Gula Kelapa Di Desa Ketanda Kabupaten Banyumas. PUBLISIA: Jurnal IImu Administrasi Publik, 2(2), 89-101

Fao. (2020). Coronavirus Disease 2019 (Covid19), Addressing The Impacts Of Covid-19 In Food Crises April-December. Food Of Agriculture Organization United Nations.

Ferreira, F.D.S., R.L.D. Costa, L. Pereira, C. Jerónimo \& A.Dias. (2018). The Relationship between Chemical of Happiness, Chemical of Stress, Leadership, Motivation and Organizational Trust: a Case Study on Brazilian Workers. Journal of International Business and Economics 6 (2):89-100.

Fitra, H. Adita. (2018). Ketahanan Masyarakat terhadap Ancaman Krisis Energi Listrik di Kabupaten Lampung Selatan, Provinsi Lampung. Jurnal Wilayah dan Lingkungan, 6(1), 58-73.

Galanakis, Caris. (2020). The Food Systems in the Era of the Coronavirus, Journal Foods, Vol. 9, No. 523, pp. 1-10.

Goetz, Stephan \& C. Schmidt. (2020). Americans' food spending patterns explain devastating impact of COVID-19 lockdowns on agriculture. Journal of Agriculture, Food Systems, and Community Development, Vol. 9, No.3, pp. 31-33.
Handayani, P.A \& Ratnasari. (2019). Pengaruh Physical Exercise terhadap Tingkat Stress pada lbu Bekerja di Sekolah Tinggi Kesehatan. Journal of Holistic Nursing and Health Science 2 (2):48-55.

Hanik, E.U. (2020). Self directed learning berbasis literasi digital pada masa pandemi Covid-19 Di Madrasah Ibtidaiyah. Elementary Islamic Teacher 8 (1):183-208.

Irfan, Maulana. (2016). Crowdfunding Sebagai Pemaknaan Energi Gotong Royong Terbarukan. Social Work Jurnal 6(1):1-153

Istanabi, T., M. S. Roychansyah, D.F. Swasto. (2018). Asimilasi sebagai Terjemahan Bentuk Adaptasi dalam Resiliensi Komunitas Kampung Kota di Kampung Sudiroprajan Surakarta. REGION: Jurnal Pembangunan Wilayah dan Perencanaan Partisipatif, 13(1):37-49.

Kamarusdiana, K. (2019). Studi Etnografi Dalam Kerangka Masyarakat Dan Budaya. SALAM: Jurnal Sosial dan Budaya Syar-i, 6(2), 113-128.

Larasati, R. (2016). Pengaruh Stres Pada Kesehatan Jaringan Periodontal. Jurnal Skala Husada 13 (1): 81 - 89.

Maslahah, H. \& R. N. Khoirunnisa. (2020). Resiliensi pada Remaja Korban Kekerasan dalam Rumah Tangga. Character: Jurnal Penelitian Psikologi, 7(2), 102-111.

Mawarpury, M \& Mirza. (2017). Resiliensi Dalam Keluarga: Perspektif Psikologi. Jurnal Psikoislamedia 2 (1):96-106.

Mawarpury, M. \& Mirza. (2017). Resiliensi dalam Keluarga: Perspektif Psikologi. Jurnal Psikoislamedia, 2(1), 96-106.

Mujahidin, E., B. Bahagia, R. Wibowo, \& F.M. Mangunjaya. (2020). Rereongan Serumpi For Rural Development In Situ Udik Village Bogor West Java. JHSS (Journal of Humanities and Social Studies) 04 (02):96 $-101$.

Naja, Farah \& R. Hamadeh. (2020). Nutrition amid the COVID-19 pandemic: a multilevel framework for action, European Journal of Clinical Nutrition.

Nathania, A., M.K. Dinata \& P.A. Griadhi. (2019). Hubungan stres terhadap kelelahan pada mahasiswa Fakultas Kedokteran Universitas Udayana. Intisari Sains Medis 10 (1): 134-138.

Nurlaila. (2017). Kompensasi Beban Dalam Persfektif Psikologi Islam. Tadrib, 2(1), 96122.

Pattipeilohy, Daniel E., dkk. (2019). Resiliensi Masyarakat Terhadap Banjir (Studi Kasus Desa Batu Merah Kecamatan Sirimau Kota 
Ambon). AGRILAN: Jurnal Agribisnis Kepulauan, 7(1), 88-105.

Pawar, Digvijay S, dkk. (2020). Impact of physical distancing due to novel coronavirus (SARS-CoV-2) on daily travel for work during transition to lockdown. Transportation Research Interdisciplinary Perspectives 7 (100203):1-10.

Petzold, M.B., A. Bendau, J. Plag, L. Pyrkosh, L.M. Maricic, F. Betzler, J. Rogoll \& J. Grobe. (2020). Risk, resilience, psychological distress, and anxiety at the beginning of the COVID-19 pandemic in Germany. Brain and Behavior 10 (9):1-10.

Poudel, Kritika \& P. Subedi. (2020). Impact of COVID-19 pandemic on socioeconomic and mental health aspects in Nepal. International Journal of Social Psychiatry 66 (8) 748-755.

Power, Madeleina, dkk. (2020). How COVID19 has exposed inequalities in the UK food system: The case of UK food and poverty, Journal Emerald Open Research, Vol. 2, No. 11, pp. 1-27.

Prime, H., M. Wade \& D.T. Browne. (2020). Risk and resilience in family well-being during the COVID-19 pandemic. American Psychologist, 75(5), 631-643.

Quraisy, $\mathrm{H} \&$ S. Asnaeni. (2017). Eksistensi Nilai Sosial Budaya A'dengkapada dalam Acara Perkawinan Masyarakat Kelara Kabupaten Jeneponto. Jurnal Equilibrium Pendidikan Sosiologi, 5(1), 44-49

Ramadania, F. \& Jamilah. (2019). Kearifan Lokal Banjar Dalam Kumpulan Cerpen Galuh Pasar Terapung Karya Hatmiati Masy'ud (Kajian Etnografi). Jurnal Tarbiyah: Jurnal Ilmiah Kependidikan, 8(1), 29-37.

Rofiq, Ainur. (2019). Tradisi Slametan Jawa dalam Perpektif Pendidikan Islam. Attaqwa: Jurnal IImu Pendidikan Islam, 15(2), 93-107.

Rusnandar, N. (2016). Beas Perelek Pemberdayaan Masyarakat di Kabupaten Purwakarta. Patanjala 8(3), 301-316.

Rutberg, S., \& C. D. Bouikidis. (2018). Focusing on the Fundamentals: A Simplistic Differentiation Between Qualitative and Quantitative Research. Nephrology Nursing Journal, 45(2) 209-213

Sampurno, M.B.T., T.C. Kusumandyoko \& M.A. Islam. (2020). Budaya Media Sosial, Edukasi Masyarakat, dan Pandemi COVID19. SALAM: Jurnal Sosial \& Budaya Syar-i 7 (6):529-542.
Scarmozzino, Federico \& F. Visioli. (2020). Covid-19 And The Subsequent Lockdown Modified Dietary Habits Of Almost Half The Population In An Italian Sample. Journal Foods, Vol. 9, No. 675, Pp. 1-8. Doi:10.3390/Foods9050675

Seran, E. Y. \& Mardawani. (2020). Kearifan Lokal Rumah Betang Suku Dayak Desa Dalam Perspektif Nilai Filosofi Hidup (Studi Etnografi: Suku Dayak Desa, Desa Ensaid Panjang Kecamatan Kelam Permai). Jurnal PEKAN, 5(1), 28-40.

Simarmata, N., K.W. Yuniarti, B. Riyono \& B. Patria (2020). Gotong Royong in Organization. International Journal of Social Welfare Promotion and Management 7 (2):1-8.

Sinaini, L., \& Iwe, L. (2020). Bentuk Kegiatan Gotong Royong Dalam Aspek Pertanian Dan Sosial Budaya Di Kabupaten Muna (Studi Kasus di Desa Langkoroni Kecamatan Maligano Kabupaten Muna). Jurnal Ilmiah Membangun Desa dan Pertanian, 5(2), 74-78.

Sisto, A., F. Vicinanza, L.L. Campanozzi, G. Ricci, D. Tartaglini \& V. Tambone. (2020). Towards a Transversal Definition of Psychological Resilience: A Literature Review. Medicina 55 (745):1-22.

Sitohang, M.Y., A.S. Rahadian \& P. Prasetyoputra. (2020). Inisiatif Masyarakat Indonesia Di Masa Awal Pandemi Covid19: Sebuah Upaya Pembangunan Kesehatan. Jurnal Kependudukan Indonesia 33-38.

Sugiyono. (2017). Metode Penelitian Pendidikan Pendekatan Kuantitatif, Kualitatif dan R\&D. Bandung: Alfabeta.

Sukmana, Oman. (2018). Pengetahuan Manajemen Bencana Dan Kearifan Sosial Di Kabupaten Malang. Sosio Konsepsia, 7(3), 190-204.

Suri, Evsa Wulan. (2017). Efektivitas Komunikasi Kepala Desa Dalam Melestarikan Tradisi Gotong Royong Di Desa Taba Pasemah Kabupaten Bengkulu Tengah. Mimbar : Jurnal Penelitian Sosial Dan Politik 6 (4):28-32.

Susilawati, R. Falefi \& A. Purwoko (2020). Impact of COVID-19's Pandemic on the Economy of Indonesia. Budapest International Research and Critics InstituteJournal 3 (2) 1147-1156.

Sutrisna, I.P.G. (2020). Gerakan Literasi Digital Pada Masa Pandemi Covid-19. Stilistika 8, (2):268-283. 
Triswanti, N. (2015). Analisis Hubungan Faktor Stres Dan Aktivitas Olahraga Dengan Kejadian Dismenore Pada Siswi Di Sekolah Menengah Atas Negeri 1 Natar Lampung Selatan. Jurnal Dunia Kesmas 4 (3):137144.

Umar, M. Zakaria. (2017). Pembangunan Rumah Tinggal dengan Sistim Arisan di Desa Pangan Jaya. EMARA: Indonesian Journal of Architecture, 3(1), 1-9

Utami, C. Tanti \& A. F. Helmi. (2017). SelfEfficacy dan Resiliensi: Sebuah Tinjauan Meta-Analisis. Buletin Psikologi, 25(1), 5465.

Utami, T.N. (2019). Tinjauan Literatur Mekanisme Zikir Terhadap Kesehatan: Respons Imunitas. Jurnal Jumantik 2 (1): $100-110$.

Vella, S.L \& N.B. Pai. (2019). A theoretical review pf psychology resilience: Defining resilience and resilience research over the decades. Arch med Health Sci 9 (7):233.

Wati, Evi Purnama \& A. Hidayah. (2017). Kearifan Lokal Menjaga Lingkungan Hidup Dalam Perspektif Ekoregion di Palembang. Bina Hukum Lingkungan 2 (1):57-69.

Widjanarko, M. (2019). 'Rembug Desa' Sebagai Bentuk Intervensi Perilaku Ekologis Pengelolaan Sampah. Jurnal Ecopsy, 6(1), 7-13.

Widyastuti, M., C. Yuliastuti, I. Farida, N.D. Rinarto, I.R. Firmansyah. (2020). Relaksasi Progresif Sebagai Penurun Tingkat Stres Pasien Kanker Dengan Kemoterapi. Jurnal Ilmiah Keperawatan Stikes Hang Tuah Surabaya 15 (1):1-16.

Windiani \& Farida Nurul R. (2016). Menggunakan Metode Etnografi Dalam Penelitian Sosial. Dimensi: Jurnal Sosiologi, 9(2), 87-92.

Yingfei, Zhang \& Zheng, Feei Ma. (2020). Impact of the COVID-19 Pandemic on Mental Health and Quality of Life among Local Residents in Liaoning Province, China: A Cross-Sectional Study. International Journal of Environmental Research and Public Health 17 (7) 2381.

Yulianti, Tri. (2019). Praktik Gotong Royong Berbasis Go Green Dalam Mewujudkan SDGs. Ettisal: Journal of Communication 4(2), 175-183.

Zaluchu, S. Eli. (2020). Strategi Penelitian Kualitatif Dan Kuantitatif Di Dalam Penelitian Agama. Evangelikal: Jurnal Teologi Injili dan Pembinaan Warga Jemaat, 3(1), 28-38.

Yeasmin, S., \& K.F. Rahman. (2012). 'Triangulation' Research Method as the
Tool of Social Science Research. Bup Journal 1 (1):154-163.

Noble, N., \& R. Heale. (2019). Triangulation in research, with examples. Evid Based Nurs 22 (3):67-68. 